\title{
Desencantamento do mundo e ética na ação pedagógica: reflexões a partir de Max Weber
}

Alonso Bezerra de Carvalho

Universidade do Estado de São Paulo

\section{Resumo}

Este artigo, de caráter teórico, apresenta ideias do pensamento weberiano, destacando aquelas que fornecem elementos para se pensar a educação na atualidade, sobretudo a partir de sua compreensão da modernidade. Desencantamento do mundo é o conceito-chave de sua sociologia, tomado como referência para refletir sobre o significado que a ciência e o professor podem ter hoje. Autor clássico, a interpretação que Max Weber faz do mundo moderno traz às nossas reflexões temas os mais diversos, influenciando sobremaneira o pensamento e a prática da cultura contemporânea, ao se preocupar em compreender as ações e os valores humanos. Ao estudar o processo de racionalização no Ocidente, provoca discussões na área da ciência, da ética e, correlativamente, na educação, possibilitando ampliarmos nosso entendimento sobre qual o sentido, o significado e o papel que devemos cumprir em relação ao conhecimento e ao ensino. 0 objetivo principal da educação é proporcionar aos alunos um conteúdo que incentive a liberdade de reflexão. Para isso, é preciso que o professor adote uma ética não partidária na sala de aula, apresentando um conteúdo que não exponha a sua opinião política e, se o fizer, que tenha a honestidade de dizer que o está fazendo. Assim, é de extrema importância que o professor mantenha uma posição "neutra” para que, não só na sala de aula, mas também fora dela, o aluno possa refletir e questionar o que observa, experimenta e decide. Somente assim a conduta do professor estaria condizente com o processo de racionalização de nossa cultura.

\section{Palavras-chave}

Modernidade - Desencantamento do mundo - Ação pedagógica - Politeísmo de valores - Ética.

Correspondência:

Alonso Bezerra de Carvalho

Av. Dom Antônio, 2100

19806-900 - Assis - SP

E-mail: alonsoprofessor@yahoo.com.br 


\title{
Disenchantment of the world and ethics in pedagogical action: reflections upon Max Weber
}

\author{
Alonso Bezerra de Carvalho
}

Universidade do Estado de São Paulo

\begin{abstract}
This article has a theoretical character and presents some of Weber's ideas, with emphasis on those that can supply elements to reflect on the current state of education, more particularly based on his understanding of modernity. Disenchantment of the world is the key concept in his sociology, and is taken as the basis for a reflection about the meaning that science and the teacher can have today. A classic author, Weber's interpretation of the modern world brings to our consideration a variety of themes that influence markedly the thinking and practice of contemporary culture by its concern with understanding human actions and values. By studying the Western process of rationalization, he initiates debates in science, in ethics and, correspondingly, in education, allowing us to expand our comprehension of the meaning, significance, and role of our actions towards knowledge and teaching. The main object of education is to offer students contents that stimulate the freedom of thought. For that, the teacher needs to adopt a non-partisan ethics in the classroom, presenting contents unbiased by her/his political opinions and, if failing to do so, having the honesty to explain what she/he is doing. It is therefore of the utmost importance that the teacher should keep a "neutral" position, so that in and out of the classroom the students may reflect and question what they see, experiment and decide upon. Only then the conduct of the teacher will be consistent with the process of rationalization of our culture.
\end{abstract}

\section{Keywords}

Modernity - Disenchantment of the world - Pedagogical action Polytheism of values - Ethics. 
No âmbito das ciências sociais, é notadamente conhecida a distinção entre a vocação científica e a vocação política. Essa distinção, central no pensamento de Max Weber, nos remete à questão da relação entre a esfera do conhecimento e a dos juízos de valor, e à discussão pedagógica que se desdobra a partir dela. Ou seja, teria o professor, ou mesmo o cientista, o poder de impor, do alto de sua cátedra, suas “avaliações práticas", isto é, seus pontos de vista pessoais e partidários, suas convicções, como regras para a vida cotidiana? No nosso entendimento, ao responder a essa questão, Weber teria formulado a sua discussão pedagógica.

Considerado um autor clássico da maior atualidade, a interpretação que Weber faz do mundo moderno traz às nossas reflexões temas os mais diversos - economia, moral, religião, política, sociologia, filosofia -, influenciando sobremaneira o pensamento e a prática da cultura contemporânea. Preocupado em compreender as ações e os valores do homem moderno, Weber entra em sintonia e se torna sensível aos dilemas que nos afligem. Ao estudar o processo de racionalização ocorrido no Ocidente, visto por ele como elemento central do que é comumente definido como modernidade, provoca discussões na área da ciência e, correlativamente, na educação, possibilitando ampliarmos o nosso entendimento sobre qual o sentido, o significado e o papel que devemos cumprir em relação ao conhecimento e ao ensino.

É verdade que Weber não escreve textos que tratam diretamente de educação, mas fornece indicações que, olhadas, com cuidado, contribuem na formulação de tipologias pedagógicas. Há passagens que explicita a sua posição sobre qual deve ser o papel do professor moderno, que também poderia se estender a todos aqueles que se dedicam à busca da verdade. Seus textos comprovam isso: o objetivo principal da educação é proporcionar aos alunos um conteúdo que incentive a reflexão. Porém, para que isto aconteça, não basta somente conteúdo, mas também a maneira como este é passado. Para isso, é preciso que o professor adote uma ética não partidária na sala de aula, ou seja, é necessário que o professor, ao apresentar um conteúdo, não exponha a sua opinião sobre ele e, se o fizer, ter a honestidade de dizer que o está fazendo. É preciso que ele incentive o aluno a refletir sobre o que foi apresentado e, então, adote uma opinião condizente com a sua compreensão. Assim, é de extrema importância que o professor mantenha uma posição "neutra" para que, não só na sala de aula mas também fora dela, o aluno possa refletir e questionar sobre o que observa, experimenta e decide. Somente assim a conduta do professor seria condizente com o processo de racionalização de nossa cultura.

0 tema da racionalização está presente nos mais variados estudos realizados por Weber, que percorrem desde a análise do surgimento do capitalismo, do poder e da burocracia, passando pelos escritos metodológicos e chegando até as investigações sobre as religiões mundiais. Tais estudos são tentativas de respostas sobre as condições em que se processaram a instauração da racionalidade do mundo moderno.

Weber foi, antes de tudo, um cientista e um professor dedicado que procurou, para o bem da ciência e do ensino, garantir a compreensão clara sobre a vida social e a integridade e a liberdade intelectual. Na conferência $A$ ciência como vocação (Weber, 1982), proferida a jovens alemães em 1918, na Universidade de Munique, e publicada em 1919, expõe uma leitura sobre o significado que a ciência adquiriu no mundo ocidental moderno, verificando em que medida ela poderia ou teria contribuído para o processo de "desencantamento do mundo" (Entzauberung der Welt).

Se aceitamos a ideia de que a ciência deveria fornecer sentido ao nosso cotidiano, para o nosso bem viver, a descrição feita por Weber certamente nos contraria. À ciência não mais caberia estabelecer uma visão de mundo que pudesse ser considerada como fator decisivo, único e último da existência humana. No mundo desencantado haveria uma infinidade de pontos de vista, perspectivas, sem que nenhum deles pudesse ser considerado como definitivo e 
sem que a vida adquirisse um sentido universal a partir dele. Nesse mundo, moderno segundo ele, os homens estariam solitários, com um grande vazio na alma, submetidos ao cálculo e ao interesse, resultado da instauração de uma racionalidade no campo da vida sócio-cultural, em que a ciência, a moral, a arte, a política e a economia adquirem leis próprias, tornando-se justificadas por uma razão que perdeu o caráter de universalidade. Essa situação teria feito com que a existência humana moderna perdesse aquele sentido teleológico, coletivo e que orientava indistintamente todas as condutas. As condições modernas, nos termos que Weber entende, teriam trazido também a possibilidade da perda de liberdade, em que a organização racional do trabalho, a burocratização, o progresso técnico/econômico, poderia até nos levar a uma configuração social que aprisiona o homem numa "gaiola dura como aço".

É dentro desse panorama que vamos situar o problema pedagógico trazido por Max Weber, isto é, qual o significado que o professor moderno adquire num mundo em que a probidade intelectual e profissional tornou-se uma exigência. Para ele, o professor não está a serviço do conhecimento e do ensino quando adota uma postura de líder, estabelecendo normas práticas/morais para a vida cotidiana de seus alunos. Do mesmo modo, nenhuma ciência estaria em condições de dizer como o homem deve viver ou ensinar às sociedades como devem organizar-se, como também não estaria em condições de captar o futuro da humanidade e nem em legitimar os seus projetos.

Na referida conferência, ele apresenta o que considera a posição que a juventude teria assumido perante o mundo civilizado. Para Weber, estariam errados os jovens que buscam no professor algo que não está à sua frente: ou seja, "anseiam por um líder". A cátedra acadêmica deveria ser ocupada somente por um professor e não por alguém que se comportasse como um líder, guiando as escolhas e ações de seu público. Enquanto o líder pretende ser um orientador nas questões que se referem à con- duta prática da vida, tal como um conselheiro na política, o professor deveria abster-se de tal ocupação, reservando-se apenas a fazer "análise e formulações de fato". 0 professor que se sente chamado a agir como conselheiro da juventude, a intervir nas lutas entre as concepções de mundo e posições partidárias, deveria fazê-lo fora da sala de aula, em lugar público, onde os seus oponentes não estão condenados ao silêncio.

Num momento brilhante de sua formulação Weber (1982) diz o seguinte, referindose, especialmente, à experiência que teve nos Estados Unidos:

0 jovem americano não tem respeito por coisa alguma, nem por ninguém, pela tradição ou pelo cargo público. A concepção que tem do professor que o enfrenta é: ele me vende seu conhecimento e seus métodos em troca do dinheiro do meu pai, tal como o verdureiro vende repolhos à minha mãe. (p. 176)

Jamais ocorreria a um jovem americano que seu professor pudesse vender uma concepção de mundo (Weltanschauung) ou um código de conduta, o que o tornaria nesse caso um treinador de futebol, isto é, um líder. "É a isso que o americano chama de "democracia"” (Weber, 1982, p. 176).

A posição do jovem americano, vista por Weber como apropriada, no sentido de esperar que o professor tenha na sala de aula um comportamento que esteja relacionado apenas com o conhecimento e com o ensino, está correlativamente associada ao significado que a ciência teria adquirido na modernidade. A ciência moderna estaria destituída da capacidade de estabelecer qualquer significado último, único e decisivo para a existência humana - o mundo teria sido despojado daquelas harmonias fictícias (a verdade universal, a natureza, a divindade e a felicidade), das quais se acreditava outrora estar constituído. Irremediavelmente especializada, impessoal e "progressista", ela teria descartado qualquer realização de resultados duradouros. Teria tornado-se apenas um meio 
indispensável da eficácia técnica, do controle prático e da clareza conceitual segundo os propósitos postos pelo homem.

Segundo Weber, no mundo moderno não temos um parâmetro com caráter universal que nos possibilite medir a validade do que a ciência pressupõe. Não temos um ponto arquimediano, com valor inquestionável e fundamental, donde podemos deduzir o seu valor. Em outras palavras, não há nenhum problema em ter pressuposto - o que na verdade toda ciência tem -, o problema é que no mundo moderno não encontramos mais um "pressuposto último" que justifique os conhecimentos que as várias áreas do saber se propõem a apreender. Desse modo, poderíamos dizer que se as ciências modernas não têm condições de legitimar, por meio de prova científica, os seus pressupostos, muito menos poderiam dar respostas que indiquem o sentido da vida dos homens. Elas são técnicas, frias, instrumentalizadas; estão impossibilitadas de dar regras para a vida prática/moral; não podem ser visões de mundo com o caráter de líderes, o que demonstra que foram desencantadas, perdendo o seu caráter mágico/profético.

Para Weber, um professor acadêmico que queira preservar sua "integridade intelectual" há de separar duas situações: a) "apresentar os fatos, determinar as relações matemáticas ou lógicas, ou a estrutura interna dos valores culturais"; e b) "responder a perguntas sobre o valor da cultura e seus conteúdos individuais e à questão de como devemos agir na comunidade cultural e nas associações políticas" (Weber, 1982, p.172-173). Em outras palavras, uma coisa seria tomar uma posição política prática, por exemplo, num comício, ao falar de democracia, em que as palavras utilizadas "não são meios de análise científica, mas meios de conseguir votos e vencer os adversários; são espadas contra os inimigos" (p. 173); outra coisa seria realizar uma análise científica em que, para continuar com o mesmo exemplo, a consideração da democracia significa examinar as suas diversas formas, o seu funcionamento, as consequências, a sua oposição às formas não democráticas etc. Seria inapropriado a um professor empregar o mesmo procedimento de um comício em uma sala de aula. Se se respeita essa distinção, o público poderá tomar a posição que quiser, em função de seus ideais.

A tarefa do professor seria, então, servir os seus alunos apenas com o seu conhecimento e com sua experiência e não impor-lhes suas opiniões políticas pessoais. 0 profeta e o demagogo não pertencem à cátedra acadêmica. Mas, quando o professor julga não poder renunciar às avaliações práticas, então que as assinale claramente como tais a seus alunos e, acima de tudo, a si próprio. Ou seja, que distinga com o máximo rigor entre os enunciados que exprimem um "conhecimento empírico" e os que exprimem "juízos de valor", pois sempre que o homem de ciência introduz seu julgamento pessoal de valor, cessa a plena compreensão dos fatos. Mas, por que, para Weber, o verdadeiro professor deveria se fazer menos como treinador de futebol e mais como verdureiro?

0 mundo desencantado teria levado os vários pontos de vista, perspectivas, valores, a um conflito mútuo inconciliável. Essa é a base da reflexão weberiana. Apesar da presença da racionalização e intelectualização nos domínios da atividade humana elas não teriam conseguido solapar o império do irracional. Ao contrário, ele teria, inclusive, se reforçado com mais intensidade, pois o homem só conseguiria racionalizar as relações exteriores, dominandoas, controlando-as e avaliando seu alcance e seus efeitos. Mas, quando se trata das opiniões, convicções, concepções de mundo pessoais, encontramos uma diversidade, impossível de unilas num todo absoluto, com valor em si mesmas. Esse conflito das várias ordens de valores é, para Weber, consequência da inexistência no mundo de um "princípio universal" que possa ser considerado o fundamento justificador de qualquer escolha valorativa, como faziam anteriormente os postulados metafísicos/religiosos.

Esse politeísmo de valores, pontos de vistas e convicções pessoais é o que encontramos quando partimos da experiência pura, quando 
levamos em consideração a dureza dos fatos desagradáveis e as realidades da vida. Isso significa que no mundo racionalizado a ciência e o professor só poderiam fornecer os meios para se agir politicamente na vida, para avaliar, porém, jamais estabelecer qualquer fim, que cada um escolherá de acordo com o significado último que dá à sua própria existência.

0 signo de nossa época, a moderna, estaria, portanto, no retorno de um novo politeísmo - agora sem encanto -, no qual a luta dos deuses toma a forma despersonalizada e objetivada de um antagonismo entre ordens de valores e ordens de vida irreconciliáveis. 0 conflito de valores, resultante desse novo politeísmo, passa a ser simplesmente insuperável, o que faz com que a ciência já não tenha mais nenhum predomínio sobre os deuses, os valores, pontos de vista, pressuposições e suas lutas. Apenas o destino, o devir histórico incontrolável e irredutível aos limites da ciência, ou seja, somente a sucessão dos fatos que podem ou não ocorrer é que validarão o ponto de vista escolhido. Quando estudarmos ou dermos uma aula sobre o divino, as suas características etc., e quisermos permanecer modernos, o máximo que poderemos fazer compreender é o que o divino significa para determinada sociedade, como fenômeno cultural, ou o que esta ou aquela sociedade considera como divino. Eis aí o limite que um professor não poderia ultrapassar enquanto ministra uma aula.

0 problema pedagógico, assim formulado por Weber (1974), teria como ponto central a ideia do professor que abdica de impor suas concepções de mundo a partir da cátedra acadêmica. Não estaríamos em condições de estabelecer pontos de vista que tivessem a função de reformar culturalmente a sociedade. Aquele professor que queira ser reformador deveria escolher o lugar apropriado, o espaço público, e não uma sala de aula. Suas opiniões pessoais não se coadunam com os fins educativos modernos, pois

de todos os tipos de profecias, a profecia professoral eivada de "personalidade" [experiência pessoal própria] é a única totalmente insuportável. [...] Porque é na verdade uma situação sem precedentes aquela em que numerosos profetas, creditados pelo Estado, em vez de pregarem pelas ruas, nas igrejas e noutros lugares [...] se arrogam o direito de declamar ex cathedra, "em nome da ciência", veredictos decisivos sobre a concepção do mundo, aproveitando-se do fato de por um privilégio do Estado, as aulas lhes concederem um silêncio aparentemente objetivo, incontrolável, que os protege da discussão e consequentemente das contradições. (p. 118-119)

Enfım, na visão de Weber, como destaca no texto $O$ sentido da 'neutralidade axiológica' nas ciências sociológicas e econômicas, publicado em 1917, caberia ao professor cumprir com propriedade sua tarefa, subtraindo sua pessoa, para servir apenas à causa do ensino e não se aproveitar da lição para fazer discurso.

No mundo desencantado, moderno, resta-nos apenas, segundo o nosso ponto de vista último, decidir qual é o Deus e qual é o demônio que mobilizam as teias de nossa existência. Neste mundo, a ciência e, por conseguinte, o professor, não teriam mais possibilidade de apresentar soluções aos problemas práticos da vida; o significado moderno que ambos adquiriram impede-os de serem colocados no sentido de dar orientações na vida prática, de se colocarem como líderes em questões de conduta. Aquele que se sente chamado a isso, ou seja, ser um conselheiro dos jovens e nisso permanecer, deveria fazê-lo tanto fora da sala de aula como fora do trabalho científico. As pluralidades de valores, os vários pontos de vista que se opõem no mundo impossibilitam-nos agir dessa maneira, pois ao nos decidirmos por uma posição nos opomos a outras, não encontrando em nenhuma delas ou fora delas o caráter de fundamento último ou princípio fundamental que pudesse nos fornecer sentido para a vida prática. Nesse aspecto, ciência, ética e política são esferas de ação humanas dotadas, cada uma, de uma legalidade própria e de uma independência que deve 
ser preservada se se quer garantir a integridade intelectual. Esse é o nosso destino, diz Weber, se quisermos permanecer fiéis a nós mesmos, homens modernos.

Agindo assim, encontramo-nos metidos num impasse. Então quer dizer que o professor não teria nenhuma contribuição a dar para o conhecimento e que de certa forma ajudasse a conduta política das pessoas? Para responder, vamos nos reportar ao significado da ciência na modernidade e, correlativamente, veremos o significado do professor.

Para Weber (1982), visto que a ciência moderna está organizada em disciplinas especializadas, fato que demonstra o caráter específico de vocação do trabalho científico, evidencia um processo de racionalização do mundo a que fomos submetidos. Segundo ele, aquele que se julga incapaz de olhar para o campo restrito de sua especialização, isto é, usar antolhos, tornando-se um especialista rigoroso, faz melhor em permanecer alheio à ciência. Isso significa dizer que a especialização nos permite experimentar a satisfação de conseguir algo duradouro, pois uma realização verdadeiramente definitiva e boa seria, em nossos tempos, sempre uma realização especializada. Enfım:

Sem essa estranha embriaguez, ridicularizada por todos os que vivem fora do ambiente; sem essa paixão; sem a certeza de saber se é capaz de fazer conjecturas; sem isso não haverá vocação para a ciência e seria melhor que vos dedicásseis a qualquer outra coisa. (p. 161)

0 trabalho científico requer a "inspiração" - aquele momento em que surge uma ideia com valor científico -, e esta é provocada pela paixão. Desse modo, mesmo considerando a ciência moderna um "problema de cálculo", auxiliada pelo entendimento frio, algo deveria ocorrer ao espírito do trabalhador científico para que surgisse uma ideia com validade para a ciência - o envolvimento do coração e da alma. Segundo Weber (1982), essa ideia, essa "intuição genial”, fruto da inspiração, não pode ser força- da, ou seja, "nada tem a ver com qualquer cálculo frio", mas é na combinação e no equilíbrio de ambas as dimensões que a ciência se realiza. Para ele, as ideias se manifestam quando elas querem e não quando nós queremos, ao estilo de um matemático ao querer alcançar qualquer resultado cientificamente valioso sentado à sua mesa com uma régua, máquina de calcular e outros meios mecânicos. Não.

As ideias chegam quando não as esperamos, e não quando estamos pensando e procurando em nossa mesa de trabalho. Não obstante, elas certamente não nos ocorreriam se não tivéssemos pensado à mesa e buscado respostas com dedicação apaixonada. (p. 162) ${ }^{1}$

Elas seriam preparadas e fecundadas no terreno fértil do trabalho árduo e profundo ao qual o cientista dedica-se apaixonadamente. Nem o trabalho - a frieza do intelecto - e nem a inspiração isoladamente fariam surgir qualquer ideia. Paixão e trabalho, especialmente quando ambos atuam ao mesmo tempo, é que criam uma ideia.

No entanto, na modernidade o caráter especializado e racional que predomina na ciência e que a reveste é evidenciado com a noção de progresso.

Toda "realização" científica suscita sempre novas "perguntas": pede para ser "ultrapassada" e superada. Quem deseja servir à ciência tem que resignar-se a tal fato. Não podemos trabalhar sem a esperança de que outros avançarão mais do que nós. (Weber, 1982, p. 164)

A inesgotabilidade e infinitude do real e a impossibilidade de lê-lo em termos totalizantes e teleológicos, teriam feito, na ótica de Weber, com que o cientista moderno concluísse que a superação do conhecimento é uma condição e um destino, ou seja, "é o sentido mesmo

1. Weber cita o caso de Ihering, que diz que as ideias chegam "ao fumarmos um charuto no sofá" ou, como Helmholtz, "quando caminhamos por uma rua que sobe lentamente" (Weber, 1982, p. 162). 
do trabalho científico". Diante disso, é possivel colocar a seguinte pergunta: como um trabalho, cujo resultado está fadado à obsolescência, pode ter sentido e razão? Por que alguém se dedica a alguma coisa que na realidade jamais chega, e jamais pode chegar, ao fim?

0 progresso científico é considerado, entretanto, por Weber (1982) como um fragmento, o mais importante, do processo de intelectualização a que estamos submetidos. Essa "racionalização intelectualista”, no entanto, não quer indicar um conhecimento maior e geral das condições sob às quais vivemos. No mundo moderno, o homem não tem um conhecimento incomparavelmente superior sobre os instrumentos que utiliza. E dá um exemplo: "a menos que seja um físico, quem anda num bonde não tem ideia de como o carro se movimenta" (p. 165). Isso é, não sabe como é construído, qual matéria-prima, o tempo e o espaço de construção etc. "Basta-lhe poder 'contar' com o comportamento do bonde e orientar a sua conduta de acordo com essa expectativa”. Inclusive dentro das diversas especialidades científicas não encontraríamos uma unidade de respostas sobre determinado assunto. Cada um terá a sua opinião de acordo com o sentido que dá à sua vida - até os físicos. 0 "selvagem", ao contrário, conhece perfeitamente os instrumentos que utiliza - por exemplo, como agir para obter o alimento cotidiano e os meios capazes de favorecê-lo em seu propósito. Nós não.

A racionalização intelectualista significa que

não há forças misteriosas incalculáveis, mas que podemos, em princípio, dominar todas as coisas pelo cálculo [pela previsão]. Isto significa que o mundo foi desencantado. Já não precisamos recorrer aos meios mágicos para dominar ou implorar aos espíritos, como fazia o selvagem, para quem esses poderes misteriosos existiam [e davam sentido à sua vida]. Os meios técnicos e os cálculos realizam o serviço. Isto, acima de tudo, é o que significa a intelectualização. (p. 165)

Diante disso nos deparamos com algo que atinge a própria existência humana. 0 cálculo e a previsibilidade teriam feito com que a vida e a morte perdessem o seu sentido ${ }^{2}$. 0 homem civilizado não encontraria mais significado na morte, porque a sua vida individual, colocada que está dentro de um progresso infinito, jamais chega ao fim,

havendo sempre um passo à frente do lugar onde estamos, na marcha do progresso. E nenhum homem que morre alcança o cume que está no infinito. 0 homem civilizado, colocado no meio do enriquecimento continuado da cultura das ideias, conhecimento e problemas, aprende [apenas] a minúscula parte do que a vida do espírito tem sempre de novo, e o que ele aprende é sempre algo provisório. (p. 166)

Abraão, exemplifica Weber, que pertencera ao mundo 'encantado', ao mundo ainda com sentido, não moderno, morrera 'velho e saciado da vida', porque estava no "ciclo orgânico da vida”, e esta lhe dera tudo o que tinha a oferecer, não havendo problema que ainda precisasse ser resolvido; o homem moderno, em contrapartida, coloca-se sempre na condição de enriquecer-se culturalmente, ou seja, pode 'cansar-se da vida', mas não 'saciar-se' plenamente dela.

Quando olhamos para o mundo moderno verificamos uma virada no significado e no valor da ciência. Se antes a ciência e a política estavam unidas - a ciência estabelecendo regras práticas/morais para os homens, dando um sentido à existência humana -, na modernidade a situação muda completamente. Para Weber, se antes as ciências exatas ou naturais esperavam descobrir traços das intenções divinas, por meio do exame da natureza, ou seja, encontrar o caminho que nos conduziria a Deus, hoje, no mundo desencantado, é raro encontrar quem acredite que os conhecimentos astronômicos, biológicos, físicos ou químicos possam ensinar-

2. Essa ideia é retomada pelos frankfurtianos ao considerarem que no "trajeto para a ciência moderna, os homens renunciaram ao sentido [...], pois o que não se submete ao critério da calculabilidade e da utilidade torna-se suspeito", anacrônico, não moderno, perigoso (Adorno; Horkheimer, 1985, p. 21). 
nos algo a propósito do sentido do mundo, pois são esses conhecimentos científicos que extirpam qualquer possibilidade de existência de significado no universo. E isso é iniciado pela filosofia bacon/cartesiana, embora nelas ainda estivesse presente uma concepção de ciência que, como técnica de domínio da natureza, nos levaria a algo que se aproximaria do bem viver.

No Discurso do método, Descartes (1987) se propõe a construir conhecimentos "que sejam muito úteis à vida", pois

conhecendo a força e as ações do fogo, da água, do ar, dos astros, dos céus e de todos os corpos que nos cercam [...] poderíamos empregá-los da mesma maneira em todos os usos para os quais são próprios, e assim nos tornar como que senhores e possuidores da natureza. (p. 63)

\section{E com isso permitindo-nos gozar dos}

frutos da terra e [de] todas as comodidades que nela se acham, mas principalmente também para a conservação da saúde, que é sem dúvida o primeiro bem e o fundamento de todos os outros bens desta vida. (p. 63)

Diferentemente, Weber (1982) considera que uma das contribuições que a ciência não poderia dar é justamente essa:

Depois da devastadora crítica feita por Nietzsche aos "últimos homens" que inventaram a felicidade, posso deixar totalmente de lado o otimismo ingênuo no qual a ciência - isto é, a técnica de dominar a vida que depende da ciência - foi celebrada como caminho para a felicidade. Quem acredita nisso? - à parte algumas poucas crianças grandes que ocupam cátedras universitárias. (p. 169)

Nesse sentido, a posição cartesiana seriam as últimas manifestações de uma concepção de ciência e de homem e, ao mesmo tempo, o alvorecer de um novo entendimento e de uma atitude que demonstraria a nossa incapacidade de atribuir um significado último e objetivo sobre o mundo. Foram destruídas as ilusões em que outrora se pautava - o caminho ao "verdadeiro Deus", à "verdadeira arte", à "verdadeira natureza”, à "verdadeira felicidade". No mundo, agora destituído de um 'valor último' que o explique e que o unifique,

a ciência é, atualmente, uma 'vocação' alicerçada na especialização e posta a serviço de uma tomada de consciência de nós mesmos e do conhecimento das relações objetivas. (Weber, 1995, p. 47)

Ela não seria mais produto de revelações, nem graça que um profeta ou visionário pudesse ter recebido para assegurar a salvação das almas. Não haveria mais lugar no mundo para essa mistificação esperançosa da ciência. 0 mundo perdeu aquele sentido universal, teleológico, como o encontrado no pensamento metafísico/religioso. Essa perda de sentido seria resultado do esvaziamento que as grandes concepções do mundo teriam sofrido. 0 mundo desencantado teria separado a busca do saber da busca do bem viver. Não se procura o saber para viver de acordo com verdades descobertas pela ciência. Essa não busca não deve e não pode ter a finalidade de indicar aos homens os caminhos que devem seguir, as normas a que devem sujeitar a sua existência. A racionalização intelectualista teria deixado no coração dos homens um grande vazio, tornando a existência humana cada vez mais fútil, menos digna de ser vivida, uma existência em que os homens se enfastiam, cansam-se e não se saciam da vida.

Se assim é, pergunta Weber, que contribuição real e positiva traz a ciência para a vida prática e pessoal? E correlativamente: teria o professor alguma contribuição a dar para o conhecimento e que de certa forma ajudasse a conduta das pessoas? Teria o professor outro significado para além do ensino?

De acordo com a explanação de Weber, a ciência e o professor poderiam, sim, dar al- 
guma contribuição para a conduta pessoal das pessoas. Apesar dos conflitos de valores, dos vários pontos de vista, dos vários deuses que lutam constantemente no mundo - circunstância que nos dificulta escolher um como o único e decisivo - é indubitável que escolhemos um valor, o nosso, que nos fará recorrer aos meios científicos para conduzir o projeto - embutido em tal valor -, a bom termo. Muitas vezes, no entanto, poderá ocorrer que tais meios escolhidos apresentem um caráter que nos obrigue a recusá-los, fato este que nos impulsionará a escolher entre o fim (o projeto) e os meios:

justificará o ‘fım' os meios? Ou não? 0 professor pode apresentar-vos a necessidade de tal escolha. Não pode fazer mais do que isso, enquanto quiser continuar como professor, e não tornar-se um demagogo. (Weber, 1982, p. 178)

Quando muito, poderia dizer as consequências que adviriam de tal escolha, e nada mais, mostrando que a posição escolhida e adotada deriva, "logicamente e com toda certeza, quanto ao significado, de tal ou qual visão última e básica do mundo" presente em nós, esclarecendo que

servimos a este deus e ofendemos ao outro deus quando resolvemos adotar uma ou outra posição. E se continuarmos fiéis a nós mesmos, chegaremos necessariamente a certas conclusões finais que, subjetivamente, têm sentido. (Weber, 1982, p. 179)

Eis o que a ciência e o professor podem proporcionar.

0 cientista e o professor, ao alcançarem e cumprirem essa incumbência, não só se colocariam a serviço de forças 'morais', mas, por conseguinte, cumpririam o dever de brotar nas almas alheias a possibilidade de se tornarem esclarecidas (Aufklärung) e o senso de responsabilidade, e seriam felizes nessa empreitada na medida em que evitassem impor ou sugerir suas convicções pessoais.
0 caráter e o destino da modernidade é que vivemos numa indiferença em relação a Deus e aos profetas e não prestaríamos nenhum serviço quando dissimulamos essa situação fundamental por meio de profecias feitas do alto de uma cátedra universitária.

0 destino de nossos tempos é caracterizado pela racionalização e, acima de tudo, pelo "desencantamento do mundo", [em que] os valores últimos e mais sublimes retiraram-se da vida pública, seja para o reino transcendental da vida mística, seja para a fraternidade das relações humanas diretas e pessoais. (Weber, 1982, p. 169)

Não seria mais possível encontrar aquele pneuma profético que arrastava as comunidades antigas e as mantinha unidas, pois ao tentarmos fabricar novas religiões e comunidades, com caráter profético, teremos os resultados mais desastrosos. E no caso da profecia professoral criaríamos seitas fanáticas, mas nunca uma comunidade autêntica.

\section{Conclusão}

Da possível concepção pedagógica weberiana emerge e exige-se uma nova conduta para o professor, se ele quiser ficar nos limites de um mundo que foi desencantado. Como não é mais possível construir valores metafísicos que orientam as ações humanas, ao professor resta criar as condições para que os cidadãos permaneçam livres para escolher o deus ou demônio que querem seguir.

De seu professor na sala de aula, o estudante deveria receber a faculdade de contentarse com a execução ponderada de uma dada tarefa; de reconhecer os fatos, mesmo os que possam ser pessoalmente desagradáveis, e de distingui-los de suas próprias avaliações. Deveria aprender, também, a sujeitar-se a sua tarefa e a reprimir o impulso de exibir desnecessariamente suas sensações pessoais 
ou outros estados emocionais. (Weber, 1995, p. 365 , grifo nosso)

Weber (1995) crê que está trazendo uma novidade para a educação. Segundo ele, se, na segunda metade do século XIX, sobretudo na Alemanha bismarckiana, a personalidade do professor deveria ser exposta em toda sua unidade, senão corria o risco de se perder; no início do século XX, ao contrário, a dedicação a uma tarefa, como ser professor ou cientista, deve ser exercida nos limites de suas atribuições, sem qualquer interferência de sentimentos de amor ou de ódio. "É de mau gosto misturar assuntos pessoais à análise especializada dos fatos". Qualquer "culto da personalidade" provoca consequências danosas e imprevistas, pois "procura dominar o trono, o serviço público ou o magistério" (p. 365). o desdobramento dessa intuição weberiana é conhecido por todos nós: o recrudescimento da burocracia e do antissemitismo. Portanto, é urgente que a nova geração aprenda a conviver com as "exigências cotidianas", comportando-se de maneira heroica e viril, entregando-se à "causa", sem esperar a constituição de uma doutrina que unifıque as crenças, os valores e oriente as ações humanas.

A partir das considerações de Weber (1995), é possível depreender que as ações pedagógicas e científicas devem caminhar lado a lado com uma "neutralidade ética". Os juízos de valor são elementos estranhos aos juízos de ordem pedagógica e científıca. É preciso distinguir um do outro. Todavia, se na atividade docente o professor deseja fazer profecias, seria honesto se permitisse que todas as avaliações pudessem ser expostas e confrontadas. Quando, numa instituição educacional, se defende a ideia de que ela está destinada a formar servidores fiéis ao Estado, estamos confundindo duas esferas heterogêneas de valores. Deixaria de ser uma instituição destinada a especialistas para tornarse um "seminário teológico, embora sem possuir a dignidade religiosa deste" (p. 366).

Weber (1995) opunha terminantemente às exclusões de professores da cátedra somente porque pensavam de maneira diferente das normas estatais ou de grupos que estavam encastelados nas Universidades. Marxistas, socialistas, anarquistas etc., eram muitas vezes excluídos dos cargos universitários porque afrontavam as opiniões hegemônicas. 0 pensamento único reinante não aceitava que suas convicções, postuladas como objetivas, fossem colocadas em dúvida. No entanto, para ele,

se se quiser fazer da universidade um fórum para a discussão de avaliações práticas, então é obviamente imperativo que se permita a mais irrestrita liberdade de discussão de questões fundamentais sob todos os ângulos. (p. 367)

Enfim, a posição de Weber (1995) é contrária àqueles professores que fazem os rostos dos alunos se iluminarem porque em suas aulas pregam as suas crenças pessoais, levando a aumentar o comparecimento dos alunos a elas. Esses professores profetas são benquistos não apenas pelos alunos, mas especialmente pelas instituições educacionais, em detrimento do estudioso muito mais ponderado e mais equilibrado que não apresenta as próprias avaliações. Aulas interessantes, com a intromissão de avaliações pessoais podem, a longo prazo, enfraquecer o gosto do estudante por análises empíricas ponderadas que, na verdade, devem ser o seu objetivo.

Entretanto, se um professor se recusa ou encontra dificuldades em deixar de proferir os seus valores numa aula, que pelo menos tenha a dignidade de "tornar perfeitamente explícito para os estudantes e para si mesmo que o está fazendo" (p. 368). A dignidade acadêmica do professor ou do cientista vem de sua responsabilidade em fazer a distinção, para si e para todos, de quando fala o homem que sabe ou ensina e o homem que avalia. Em Weber (1982), então, não há uma oposição àqueles que tem convicções e acreditam nelas, mas o que ele enfatiza é a necessidade de equilibrá-las adotando uma perspectiva responsável. Desse ponto de vista, um bom professor tem às vezes que 
lançar mão das três qualidades que um político deve ter, expostas em A politica como vocação, também publicada em 1919, isto é, paixão, senso de responsabilidade e sendo de proporção.

À guisa de conclusão e segundo o ponto de vista de Max Weber, se é possível construir uma ação educativa na modernidade, ela deve estar fundada num questionamento permanente de suas próprias condições. No final do texto A ética protestante e o espírito do capitalismo, lançado em 1904-1905 e ampliado em 1920, Weber (2004) afirma a necessidade do surgimento de novos pensamentos e de novos ideais para contraporem-se a um mundo que transformou o homem num ser insensível e calculista. Ele aponta para a possibilidade de rompermos com o estado de coisas originado no capitalismo moderno. Portanto, é preciso pensar numa terapia das condições modernas. Essa terapia deve ser de tal maneira que desconfie da razão, via ciência e via educação, que se coloca como um princípio ordenador da relação homem/mundo, expressa no caráter burocrático da existência. o burocrata ou o "espírito de peso", como diz Nietzsche, julga que existem leis universais, e acredita que há regras de conduta válidas para todos. Estabelecendo coerção, norma, zela pelos valores instituídos e estatuídos.

Nesse sentido, retomar o espírito carismático e o dionisíaco pode ser o "caminho" para aqueles que querem a liberdade. A educação pode nos ajudar nesse processo. Ao invés de uma vida fundada na rigidez, na frieza e no cálculo, experimentar a sensação fornecida pelo movimento que resulta da dança. Ver a vida como dança, como um jogo, é pôr em cena variados pontos de vista, diferentes perspectivas, fazendo surgir aspectos inesperados da existência. Com a dança, evoca-se o fluxo vital; com ela, alude-se à permanente mudança de tudo o que existe, contra qualquer dogmatismo. Pondo sob suspeita toda e qualquer certeza, antecipa ideias para fazer experimentos com o pensar. Cadência, a dança põe em xeque a aparente imobilidade das coisas, a rigidez imposta ao pensamento e à vida. A dança é ainda alegria, alegria dionisíaca. Assim, podemos pensar numa educação que leve em conta a dança alegre dionisíaca e o espírito estático do carisma.

Como na ação carismática, é preciso orientar a vida a partir da desconfiança, evitando as convicções; abandonar comodidades, renunciando à segurança. É preciso ousadia para abrir mão de antigas concepções, libertar-se de esperanças vãs. Assim diz Nietzsche (1978):

[...] Onde um homem chega à convicção fundamental de que é preciso que mandem nele, ele se torna "crente"; inversamente, seria pensável um prazer e força a autodeterminação, uma liberdade da vontade, em que um espírito se despede de toda crença, de todo desejo e possibilidades, e mesmo diante de abismos dançar ainda. Um tal espírito seria o espírito livre par excellence. (p. 215)

Enfım, é necessária uma educação que faça um movimento de ressurgimento, introduzindo no mecanismo determinista o espaço de libertação, que consiste em romper o determinismo inerente a qualquer situação objetiva e, de forma desviante, abrir espaço para o exercício da autonomia. Ser mortal, o homem constrói sua liberdade no tempo, no tempo desta vida que deve ser transformado em tempo de felicidade. Para isso, Weber vai considerar necessário que enfrentemos o mundo burocrático, que estabelece um cenário racional, para que o mundo e a vida não deixem de ser apenas uma possibilidade abstrata. Essa deve ser a responsabilidade da ação educativa. 


\section{Referências bibliográficas}

ADORNO, T. W.; HORKHEIMER, M. Dialética do esclarecimento. Rio de Janeiro: Zahar, 1985.

DESCARTES, R. 0 discurso do método. São Paulo: Nova Cultural, 1987.

NIETZSCHE, F. Obras incompletas. São Paulo: Abril Cultural, 1978.

WEBER, M. Ciência e política: duas vocações. São Paulo: Cultrix, 1995.

Ensaios de sociologia. Rio de Janeiro: Guanabara, 1982.

A ética protestante e o "espírito" do capitalismo. São Paulo: Companhia das Letras, 2004.

Metodologia das ciências sociais. Tradução Augustin Wernet. Introdução à edição brasileira de Maurício Tragtenberg. São Paulo: Cortez, 1995. (Parte 2).

Sobre a teoria das ciências sociais. Lisboa: Presença, 1974.

Recebido em 08.09.09

Aprovado em 04.05.10

Alonso Bezerra de Carvalho é graduado em Filosofia e Ciências Sociais pela U-NESP, mestre e doutor em Educação pela USP. Pós-Doutor em Ciências da Educação na França. Tem experiência na área de Educação, com ênfase em Filosofia e Sociologia da Educação, atuando principalmente nos seguintes temas: ética, educação, modernidade, racionalização, relação professor/ aluno, amizade e sala de aula. 